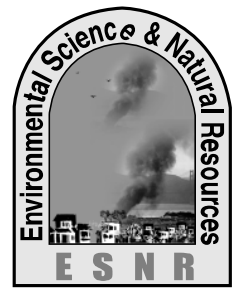

J. Environ. Sci. \& Natural Resources, 6(2): 191-196, 2013

ISSN 1999-7361

\title{
Culture Practice of Thai Koi (Anabas Testudineus) With Different Stocking Densities at Tarakanda in Mymensingh District
}

\author{
B. K. Roy ${ }^{1}$, S. N. Pattadar ${ }^{2}$, M. E. Ahsan ${ }^{3}$, M. J. Alam ${ }^{4}$ and M. M. Ali ${ }^{1}$ \\ ${ }^{1}$ Dept of Aquaculture, Bangladesh Agricultural University, Mymensingh \\ ${ }^{2}$ Dept of Aquaculture, ${ }^{3}$ Dept. of Marine Fisheries and Oceanography, ${ }^{4}$ Dept. of Fisheries Management, \\ Patuakhali Science and Technology University
}

\begin{abstract}
The present experiment was conducted to study the culture practice of Thai Koi (Anabas testudineus) with different stocking densities and their growth performance. The study was carried out over a period of 76 days from 22 June, 2008 to 05 September, 2008 in Tarakanda upazila of Mymensingh district. For the study, the experiment was undertaken with 3 treatments $\left(T_{1}, T_{2}\right.$ and $\left.T_{3}\right)$ each having two replications $\left(R_{1}\right.$ and $\left.R_{2}\right)$. Three different stocking densities designed as treatments viz., 550 in $T_{1}$, 400 in $\mathrm{T}_{2}$ and 350 fry /dec in $\mathrm{T}_{3}$. The fry of same size (length $2.45 \mathrm{~cm}$ and weight $5 \mathrm{~g}$ initially) were stocked and they were fed with commercial pelleted feed according to their body weight. At the very beginning $16 \%$ feed were provided with frequency 4 times in a day. It was decrease up to $4.5 \%$ before 10 days of harvesting. During the experiment period, water quality was asses sed fortnightly. The average temperature was found $28.21 \pm 0.87^{0}, 28.78 \pm 0.51^{0}$ and $28.76 \pm 0.78^{0} \mathrm{C}$ in treatments $\mathrm{T}_{1}, \mathrm{~T}_{2}$ and $\mathrm{T}_{3}$ respectively. The $\mathrm{pH}$ ranges were varied between 7.70 to 9.10 among the three treatments. The mean values of dissolve oxygen were $5.33 \pm 0.34,4.23 \pm 0.13,4.16 \pm 0.14 \mathrm{mg} / \mathrm{L}$ respectively in the three consecutive treatments. The growth performance was determined by measuring length $(\mathrm{cm})$ and weight $(\mathrm{g})$. Treatment-3 where stocking density was less showed the best growth performance followed by $\mathrm{T}_{1}$ and $\mathrm{T}_{2}$. The production was higher $8719.10 \mathrm{~kg} / \mathrm{ha}$ in $\mathrm{T}_{1}$ was obtained from this treatment.
\end{abstract}

Key wards: Cultural Practice, Stocking density, Thai Koi (Anabas testudineus)

\section{Introduction}

The Koi, (Anabas testudineus) naturally occurs in Bangladesh, India, Pakistan, Ceylon, Myanmar, Srilanka, Thailand, Cochin-China, Tongking, Souththern China, Philippines, Polynesia and Malaysia ( Sterba, 1983; Sen, 1985; Talwar and Jhingram, 1991). Once upon a time, climbing perch or Koi was very much abundant in almost all freshwater systems of Bangladesh (Mahmood, 2003). The availability of this fish is decreasing from natural system in the recent years. Ten years ago, Koi itself contributed $2.83 \%$ of the total pond catch of Bangladesh and gradually contribution declined to $0.85 \%$ (DoF, 1999). The reasons behind of severe decline of Koi fishes are ecological degradation, indiscriminate use of pesticides, destruction of habitats, obstruction of breeding migration and fishing pressure etc. Since the natural production of Koi is decreasing, fisheries biologists are thinking of its cultivation through intensive farming (DoF, 2002).

Very recent Koi fish has been introduced to our culture arena. It has a great demand in the market for its nutritive value and taste. Due to culture of Koi, brood and fry had been brought from Thailand with high price. Now it is being bred successfully in our country. Bangladesh Fisheries Research Institute (BFRI) developed the induced breeding and culture technology of exotic Koi. Many hatcheries have been established in our country with a view to producing Koi fry. Specially greater Mymensingh, Gazipur and Bogra are playing prominent role in this regard.
The reasons behind the greater expansion of Thai Koi culture in Bangladesh are: a) The fish can tolerate our environment easily; b) It is cultivable under high stocking density; c) It is cultivable in deep or shallow water; d) They can survive in low oxygen level; e) It can be marketed at live condition; f) Crop can be attained within 3-4 months; g) Since it is nutritive and tasty so, it can be used as patient food. The present price of Thai Koi in the market is near about 150-160 Tk./kg. Thai Koi looks like our indigenous Koi but its body covers with gray color and small black spots. This fish is cultivable in ponds, tanks and cages successfully. It is tough to culture our indigenous Koi in pond providing supplementary feed to culture Thai Koi in pond successfully supplying artificial feed. The present study was under taken to evaluate performance level of different Stocking Densities.

\section{Materials and methods}

\section{Area and time span of the Study}

The experiment was carried out in the Tarakanda upazila of Mymensingh district from 22 June, 2008 to 05 September, 2008.

\section{Description of Experimental units}

Six earthen ponds (numbered as pond 1, 2, 3, 4, 5 and 6) were selected at Tarakanda under Mymensingh district for the experimental purpose. The ponds were rectangular in shape and each pond was 50 decimal in size. Water depths of each pond were 4 feet. The ponds were free from aquatic vegetation and flood. They were exposed to sunlight. The ponds were fully independent and there were no any inlet and outlet 
facilities. Water source of the ponds were shallow tube-well.

\section{Design of experiment}

The experiment was undertaken with 3 treatments $\left(T_{1}\right.$, $\left.T_{2}, T_{3}\right)$ each having two replications $\left(R_{1}, R_{2}\right)$. Pond 1 and 2 were treated as $T_{1}$, pond 3 and 4 were treated as $\mathrm{T}_{2}$ and pond 5 and 6 were treated as $\mathrm{T}_{3}$. Three different stocking densities designed as treatments in the experimental ponds were; $550 \mathrm{Koi}$ fry/dec in the $\mathrm{T}_{1}, 400 \mathrm{Koi}$ fry/dec in the $\mathrm{T}_{2}$ and $350 \mathrm{Koi}$ fry/dec in the $T_{3}$ respectively. The same sizes fry were stocked for the research purpose.

\section{Pond preparation}

The research ponds were dried before the stocking of fry. After pond water had been pumped out the ponds were exposed to sunlight for about 2 weeks. Pond dykes were renovated where necessary. The excessive bottom mud was removed from the pond. Liming was done for each pond at the rate of $172 \mathrm{~g} / \mathrm{dec}$. After 7 days of liming 6 experimental ponds were filled up with water up to 4 feet through shallow machine that was run by electricity. After that, the research ponds were well fenced by nylon net with the support of bamboo sticks.

\section{Collection of fry/Source of fry and Stocking}

The fry of Thai Koi (Anabas testudineus) were collected from "Tauki Matsha Projonon Kendra" Tarakanda, of Mymensingh district. Before stocking the fry in the experimental ponds, it was reared about 1 month in a nursery pond. When fry became about $2.54 \mathrm{~cm}$ in length and their weight were about $5 \mathrm{~g}$, it was stocked in the research ponds. The initial data (length and weight) were recorded before releasing in to the ponds.

\section{Feeding}

The stocked fry were fed 4 times in a day with commercial pelleted feed (Saudi bangla or Quality). At the beginning, starter-2 feed was supplied at the rate of $16 \%$ of their body weight which gradually decreased to $4.5 \%$. When the fish weighed about 21 $30 \mathrm{~g}$, feed was decreased to $10 \%$ of their body weight. Before 10 days of harvesting the feeding rate became $4.5 \%$ of the fish body weight and that time feeding frequency was 3 times in a day. It is notable that same types of feed were provided to each pond.

\section{Monitoring and data collection}

Growth monitoring was done at 15 days interval in the morning and the fish were caught with the help of small ber jal. The length and weight recorded in a note book by random sampling of 5 fishes from each pond. Length was measured by using a centimeter scale and weight by using a balance.

\section{Water quality assessment}

Water quality parameters were assessed every 15 days interval. Mainly $\mathrm{pH}$, dissolve oxygen (DO), and temperature were recorded. Dissolve oxygen and $\mathrm{pH}$ were recorded by respective digital meter and the temperature by Celsius thermometer.

\section{Harvesting}

Harvesting was done at the evening of 5 September 2008. Fish were harvested by ber jal.

\section{Growth performance and production of fish}

The following formulae were applied to calculate the growth performance and production of fish.

1) Length gain $(\mathrm{cm})=$ Average final length - Average initial length

2) Weight gain $(\mathrm{g})=$ Average final weight - Average initial weight

3) Specific growth rate $=\left(\mathrm{LnW}_{2}-\mathrm{LnW}_{1}\right) /\left(\mathrm{T}_{2}-\mathrm{T}_{2}\right)$

4) Survival rate $=$ Initial number of fish - final number of fish / Initial number of fish $\times 100$

5) Production of fishes: Net Production= No. of fish caught $\times$ average final weight

\section{Data analysis}

All the data that were collected during the experimental period recorded in note book and then transferred in Computer. Finally the data were processed and analyzed statistically by using Microsoft Excel program and statistical software SPSS, Version 12.0 (Inc., Chicago, USA).

\section{Results and Discussion}

\section{Physical parameters \\ Temperature}

Temperature plays a vital role in respect of fish production. In the present study the average temperature were recorded $28.21 \pm 0.87{ }^{\circ} \mathrm{C}$, $28.78 \pm 0.511^{\circ} \mathrm{C}$ and $28.76 \pm 0.78{ }^{\circ} \mathrm{C}$ in $\mathrm{T}_{1}, \mathrm{~T}_{2}$ and $\mathrm{T}_{3}$ respectively and temperature ranged from $27.30^{\circ} \mathrm{C}$ to $29.60^{\circ} \mathrm{C}$ during the experimental period (Table 1). Actually there was no significant difference of temperature among three treatments but those values were within the acceptable ranges for fish culture. Kohinoor (2000) observed the water temperature ranged from 24.2 to $33.30^{\circ} \mathrm{C}$, suitable for fish culture.

\section{Chemical parameters}

\section{Dissolve Oxygen (DO)}

During the experimental period the average dissolve oxygen level were $5.33 \pm 0.34,4.23 \pm 0.13$ and $4.16 \pm 0.14 \mathrm{mg} / \mathrm{L}$ in $\mathrm{T}_{1}, \mathrm{~T}_{2}$ and $\mathrm{T}_{3}$ respectively. The maximum value of dissolve oxygen was found 5.70 $\mathrm{mg} / \mathrm{L}$ in pond 1 under the $\mathrm{T}_{1}$ and the minimum value of dissolve oxygen was $4.00 \mathrm{mg} / \mathrm{L}$ in the pond 5 and 6 under the $\mathrm{T}_{3}$ (Table 1). According to Ahsan (2013) 
dissolve oxygen content should be $5 \mathrm{mg} / \mathrm{L}$ or more for a productive pond. DoF (1996) reported that the range of dissolve oxygen content for fish culture should be $5.0-8.0 \mathrm{mg} / \mathrm{L}$. In the $\mathrm{T}_{1}$, dissolve oxygen level was fine and was not varied significantly due to continuous water flow. In spite of stocking density high in the $T_{1}$, survival rate and growth rate of Thai Koi was notably good. It can be concluded that dissolve oxygen level in the $\mathrm{T}_{1}$ was impressive and very much productive for fish culture. Treatment-2 and 3 was not so worse because Koi can survive under a low oxygen level.

\section{Hydrogen ion concentration ( $\mathrm{pH})$}

$\mathrm{pH}$ in the water body absolutely is an important factor for successful fish culture. Abrupt change of $\mathrm{pH}$ in the culture system may hamper the production alarmingly. In the present study the range of $\mathrm{pH}$ at different treatmentare shown in Table 1. Average values of $\mathrm{pH}$ in the treatments were $8.40 \pm 0.31$, $8.49 \pm 0.20$ and $8.44 \pm 0.23$ throughout the study period in $T_{1}, T_{2}$ and $T_{3}$ respectively. For pond fish culture, the suitable range of $\mathrm{pH}$ is 6.5 to 8.5 (Boyd, 1992). Uddin (2002) recorded that the $\mathrm{pH}$ value ranging from 6.24 to 8.88 .

Table 1. Overall mean values of water quality parameters of six ponds under three treatments with $( \pm \mathrm{SD})$

\begin{tabular}{lccc}
\hline Parameters & $\mathbf{T}_{\mathbf{1}}$ & $\mathbf{T}_{\mathbf{2}}$ & $\mathbf{T}_{\mathbf{3}}$ \\
\hline \multirow{2}{*}{ Temperature $\left(0^{0} \mathrm{C}\right)$} & $28.21 \pm 0.87$ & $28.78 \pm 0.51$ & $28.76 \pm 0.78$ \\
& $27.30-29.50$ & $27.50-29.2$ & $27.50-29.60$ \\
Dissolve oxygen $(\mathrm{mg} / \mathrm{L})$ & $5.33 \pm 0.34$ & $4.23 \pm 0.13$ & $4.16 \pm 0.14$ \\
& $4.40-5.7$ & $4.10-4.50$ & $4.00-4.40$ \\
$\mathrm{pH}$ & $8.40 \pm 0.31$ & $8.49 \pm 0.20$ & $8.44 \pm 0.23$ \\
& $7.90-9.00$ & $8.10-9.10$ & $7.70-8.7$ \\
\hline
\end{tabular}

\section{Stocking and survival rate of Thai Koi}

The experiment was carried out for 76 days under three stocking densities: 550 fry/dec in $\mathrm{T}_{1}, 400$ in $\mathrm{T}_{2}$ and 350 in $\mathrm{T}_{3}$. In the present study, survival of Koi was high because they can survive under adverse condition like; low oxygen, high temperature and high $\mathrm{pH}$ value. The survival rate was recorded
$90.72 \%, 93.25 \%$, and $95.05 \%$ in $\mathrm{T}_{1}, \mathrm{~T}_{2}$, and $\mathrm{T}_{3}$, respectively at harvesting time (Table 2). In the treatment-3 the higher survival rate was found because of low density than the other two treatments but there was no significant level of variation in survival rates in treatments.

Table 2. Survival rate of Thai Koi under different treatments

\begin{tabular}{|c|c|c|}
\hline Treatments & Replications & Survival rate (\%) \\
\hline \multirow{2}{*}{$\mathbf{T}_{1}$} & Replication & 90.90 \\
\hline & Replication & 90.54 \\
\hline \multirow{2}{*}{$\mathbf{T}_{2}$} & Replication & 93.50 \\
\hline & Replication & 93.00 \\
\hline \multirow{2}{*}{$\mathbf{T}_{3}$} & Replication & 94.71 \\
\hline & Replication & 95.42 \\
\hline
\end{tabular}

\section{Specific growth rate (SGR)}

The specific growth rate of Thai Koi was found 3.57, 3.65 and 3.72 in the three treatments $\mathrm{T}_{1}, \mathrm{~T}_{2}$, and $\mathrm{T}_{3}$ respectively Table 3. The specific growth rate of Thai Koi among the three treatments was not varied significantly.

Table 3. Specific growth rate of Thai Koi during the study period

\begin{tabular}{|c|c|c|}
\hline Treatments & Replications & Specific growth rate (SGR) \\
\hline \multirow{2}{*}{$\mathbf{T}_{1}$} & Replication & 3.570 \\
\hline & Replication & 3.577 \\
\hline \multirow{2}{*}{$\mathbf{T}_{2}$} & Replication & 3.657 \\
\hline & Replication & 3.648 \\
\hline \multirow{2}{*}{$\mathbf{T}_{\mathbf{3}}$} & Replication & 3.723 \\
\hline & Replication & 3.724 \\
\hline
\end{tabular}




\section{Growth rate of Thai Koi}

Growth and production of Thai Koi in the six ponds under three treatments were recorded fortnightly. The growth was measured by weighing their lengths $(\mathrm{cm})$ and weights $(\mathrm{g})$. The average length gain in the $\mathrm{T}_{1} \mathrm{~T}_{2}$ and $\mathrm{T}_{3}$ were $11.96 \pm 0.03 \mathrm{~cm}, 12.24 \pm 0.01 \mathrm{~cm}$ and $12.51 \pm 0.08 \mathrm{~cm}$ respectively (Table 4 ). The significant difference was not found between $T_{1}$ and $T_{2}$. Relatively high level of growth was found in $T_{3}$. The average weight gain of Thai Koi at the harvesting time was $70.62 \pm 1.25,75.08 \pm 0.69$ and $79.75 \pm 0.75 \mathrm{~g}$ in the $\mathrm{T}_{1}, \mathrm{~T}_{2}$ and $\mathrm{T}_{3}$ respectively. The highest weight was found in $\mathrm{T}_{3}$.

Table 4. Fortnightly growth rate of Thai Koi (A. testudineus) by average weight $(\mathrm{g})$ and Length (cm) under different treatments during study period

\begin{tabular}{|c|c|c|c|c|c|c|c|c|}
\hline Item & Treatment & $\begin{array}{c}22 \text { Jun } \\
\text { Initial Wt. }\end{array}$ & 07 July & 22July & $6 \mathrm{Aug}$ & $21 \mathrm{Aug}$ & $\begin{array}{c}05 \mathrm{Sep} \\
\text { Final Wt }\end{array}$ & $\begin{array}{c}\text { Net } \\
\text { average }\end{array}$ \\
\hline \multirow{3}{*}{ 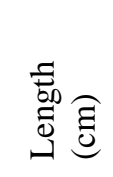 } & 1 & $2.54 \pm 0.00$ & $5.02 \pm .01$ & $7.02 \pm 0.01$ & $10.05 \pm 0.01$ & $11.82 \pm 0.01$ & $14.50 \pm 0.03$ & $11.96 \pm 0.03$ \\
\hline & 2 & $2.54 \pm 0.00$ & $5.54 \pm .01$ & $7.64 \pm 0.01$ & $10.51 \pm 0.01$ & $12.42 \pm 0.01$ & $14.78 \pm 0.01$ & $12.24 \pm 0.01$ \\
\hline & 3 & $2.54 \pm 0.00$ & $5.60 \pm .01$ & $7.71 \pm 0.01$ & $10.66 \pm 0.01$ & $12.54 \pm 0.01$ & $15.05 \pm 0.08$ & $12.51 \pm 0.08$ \\
\hline \multirow{3}{*}{$\begin{array}{l}\text { O00 } \\
\dot{3}\end{array}$} & 1 & $5.00 \pm 0.00$ & $16.06 \pm 1.41$ & $35.07 \pm 1.17$ & $56.16 \pm 1.07$ & $70.62 \pm 0.87$ & $75.62 \pm 1.25$ & $70.62 \pm 1.25$ \\
\hline & 2 & $5.00 \pm 0.00$ & $18.75 \pm 0.55$ & $38.06 \pm 0.56$ & $57.57 \pm 0.59$ & $72.22 \pm 0.03$ & $80.08 \pm 0.69$ & $75.08 \pm 0.69$ \\
\hline & 3 & $5.00 \pm 0.00$ & $20.37 \pm 0.63$ & $40.39 \pm 0.68$ & $60.23 \pm 0.09$ & $74.91 \pm 0.23$ & $84.75 \pm 0.45$ & $79.75 \pm 0.75$ \\
\hline
\end{tabular}

\section{Production of Thai Koi}

At the end of the experiment, the net yield of Thai Koi were $8719.10,6916$ and $6553.11 \mathrm{~kg} / \mathrm{ha}$ in $\mathrm{T}_{1}, \mathrm{~T}_{2}$ and $\mathrm{T}_{3}$ respectively. The highest yield was found in the $\mathrm{T}_{1}$ and then followed by $\mathrm{T}_{2}$ and $\mathrm{T}_{3}$. The result of production significantly varied from $\mathrm{T}_{1}$ to $\mathrm{T}_{2}$ and $\mathrm{T}_{3}$ respectively. The production scenario is shown in figure 1 .

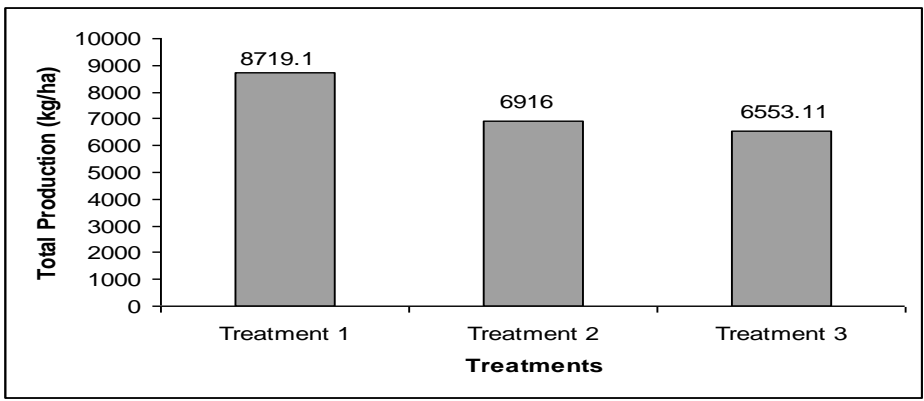

Fig. 1. Total production of Thai Koi (A. testudineus) in $\mathrm{kg} / \mathrm{ha}$ under three treatments

Table 5. Growth, survival and production of Thai Koi (A. testudineus) under different treatments

\begin{tabular}{cccccccccc}
\hline Treatment & $\begin{array}{l}\text { Stocking } \\
\text { density }\end{array}$ & $\begin{array}{l}\text { Average } \\
\text { initial } \\
\text { weight }(\mathrm{g})\end{array}$ & $\begin{array}{l}\text { Culture } \\
\text { period } \\
\text { (days) }\end{array}$ & $\begin{array}{l}\text { Pond area } \\
\text { (decimal) }\end{array}$ & $\begin{array}{l}\text { Average } \\
\text { harvesting } \\
\text { weight }(\mathrm{g})\end{array}$ & & $\begin{array}{c}\text { Production }(\mathrm{kg}) / \\
\text { Deci } \\
\text { mal }\end{array}$ & $\begin{array}{c}\text { Surviv } \\
\text { al rate } \\
(\%)\end{array}$ & $\begin{array}{c}\text { SGR } \\
(\% \text { day })\end{array}$ \\
\hline $\mathrm{T}_{1}$ & 550 & 5.00 & 76 & 1 & 75.62 & 35.30 & 8719.1 & 90.90 & 3.57 \\
$\mathrm{~T}_{2}$ & 400 & 5.00 & 76 & 1 & 80.08 & 28.00 & 6916.0 & 93.25 & 3.65 \\
$\mathrm{~T}_{3}$ & 350 & 5.00 & 76 & 1 & 84.75 & 26.53 & 6553.1 & 95.05 & 3.72 \\
\hline
\end{tabular}




\section{Cost-benefit analysis \\ Gross cost}

The average cost of Thai Koi fry was $962.50 \mathrm{Tk}$. in the $\mathrm{T}_{1}, 700 \mathrm{Tk}$. in the $\mathrm{T}_{2}$ and $612.50 \mathrm{Tk}$. in the $\mathrm{T}_{3}$. Each of the fry was bought at $1.75 \mathrm{Tk}$. The cost of Saudi Bangla feed supplied to the ponds was 27.50 $\mathrm{Tk}$. per $\mathrm{kg}$ and for the culture purpose 2062.50, 1787.50, and $1650.00 \mathrm{Tk}$. were invested in $\mathrm{T}_{1}, \mathrm{~T}_{2}$ and $\mathrm{T}_{3}$ respectively. Including pond preparation cost, labour cost and other management cost, the gross cost was as $3745.00,3207.50$ and $2982.50 \mathrm{Tk}$. in the treatments $T_{1}, T_{2}$ and $T_{3}$ respectively. Gross costs of different treatments are given in Table 5 .

\section{Gross income}

Gross income was calculated by multiplying total production and market price. The gross incomes from the three treatments $\left(T_{1}, T_{2}\right.$ and $\left.T_{3}\right)$ were $6001.00 \mathrm{Tk}$,
$4760 \mathrm{Tk}$ and 4510.10Tk. per decimal respectively Table 6 .

\section{Net income}

Net income was estimated by deducting gross cost from gross income. The net profit was $2256.00 \mathrm{Tk}$. in $\mathrm{T}_{1}, \quad 1552.5 \mathrm{Tk}$. in $\mathrm{T}_{2}$ and $1527.6 \mathrm{Tk}$. in $\mathrm{T}_{3}$ respectively. The net profit was higher in $T_{1}$, and then followed by $\mathrm{T}_{2}$ and $\mathrm{T}_{3}$ (Table 6 )

\section{Benefit-cost ratio $(B C R)$}

$\mathrm{BCR}$ was calculated as the ratio of gross income to gross cost. The BCR was found in the there treatments $\mathrm{T}_{1}, \mathrm{~T}_{2}$ and $\mathrm{T}_{3}$ viz., 1.6, 1.48, and 1.51 respectively. The highest $\mathrm{BCR}$ was found in $\mathrm{T}_{1}$ (1.60), and the lowest one was found in $\mathrm{T}_{2}$ (1.48) (Table 6).

Table 6. Cost- benefits analysis of Thai Koi (Anabas testudineus) in ponds at the end of study period.

\begin{tabular}{lccc}
\hline Item & $\mathbf{T}_{\mathbf{1}}$ & $\mathbf{T}_{\mathbf{2}}$ & $\mathbf{T}_{\mathbf{3}}$ \\
\hline Expenditure (Tk) & & & 200.00 \\
\hline Pond preparation & 200.00 & 200.00 & 612.50 \\
Price of fry & 962.50 & 700.00 & 20.00 \\
Liming & 20.00 & 20.00 & 1650.00 \\
Feed & 2062.5 & 1787.50 & 300.00 \\
Man power & 300.00 & 300.00 & 200.00 \\
Others & 200.00 & 200.00 & 2982.50 \\
Gross cost/dec & 3745.00 & 3207.50 & \\
\hline & & & 4510.10 \\
\hline Income (Tk.) & & & 1527.6 \\
\hline Gross income/dec (Tk.) & 6001.00 & 4760.00 & 1.51 \\
Net profit (Tk.) & 2256.00 & 1552.50 & 1.48 \\
BCR & 1.60 & & \\
\hline
\end{tabular}

\section{Conclusion and Recommendation}

In the present study it has been showed that the highest growth rate was found in $\mathrm{T}_{3}$ compared with $\mathrm{T}_{1}$ and $\mathrm{T}_{2}$; production was less, although there stocking density and overall production less than the $\mathrm{T}_{1}$ and $\mathrm{T}_{2}$. But the major emphasized that using same area to maximize output. Thai Koi can tolerate crowding condition they can be cultured intensively in the farmers pond to raise the production and for success. Farmers have to have deep concentration on the management issues. It can be stated that high stocking may also economic and beneficial for Thai Koi culturists. Therefore, Improvement of culture technology and successful breeding performance can increase Thai Koi production in Bangladesh.

\section{References}

DoF (Department of Fisheries). 1992. Fish Catch Statistics of Bangladesh 1991-1992. Department of Fisheries, Dhaka, Bangladesh, 41 pp.

DoF (Department of Fisheries). 1996. Matsha Pakkha Sankalan (Bengali). 1996. Dept. of Fisheries, Ministry of Fisheries and Livestock, People's Republic of Bangladesh. $81 \mathrm{p}$.

DoF (Department of Fisheries). 1999. Fish Catch Statistics of Bangladesh 1998-1999. Department of Fisheries, Dhaka, Bangladesh, 41 pp.

DoF (Department of Fisheries). 2002. Fisheries fortnight' 02 compendium. Department of 
Fisheries, Ministry of Fisheries and Livestock, Government of the People's Republic of Bangladesh, Dhaka. 87 pp.

Kohinoor, A.H.M. 2000. Development of culture technology of three small indigenous fishmola (Amblypharyngodon mola), punti (Puntius sophore) and chela (Chela cachius) with notes on some aspects of their biology. Ph.D. dissertation, Dept. of Fisheries Management, Bangladesh Agricultural University, Mymensingh. 363 p.

Mahmood, S. U. 2003. Effects of Pituitary gland extracts doses on the breeding performance of Koi fish, Anabas testudineus (Bloch 1972). Bangladesh J. Zool., 31(2): 195-201.

Ahsan, M. E. 2013. Impacts of inclusion of column feeder rohu (Labeo rohita) at different stocking densities on growth, production and environment in freshwater prawn-carp-mola polyculture system International Journal of Biological Research, 1 (2): 48-54.
Rahman, M. S. 1992. Water Quality Management in Aquaculture. Published by Bangladesh Rural Advancement Committee. 7 p and 75 pp.

Sen, T. K. 1985. The Fish Fauna of Assam and Neighboring North-eastern States of India. Records of the Zoological Survey of India, Miscellaneous Publication, Occasional Paper No. 64. Calcutta, 217 pp.

Sterba, G. 1983. The Aquarium Fish Encyclopedia. The MIT Press. Cambrige, Masschusetts, $605 \mathrm{pp}$.

Talwar, P. K. and A. G. Jhingram. 1991. Inland fishes of India and adjacent countries. Volume 2. A.A. Balkema, Rotterdam.

Uddin, M. M. 2002. Effect of addition of small fish on pond ecology and production in polyculture. M.S. Thesis. Department of Fisheries Management. Bangladesh Agricultural University, Mymensingh. 81 pp. 